\title{
Corruption Prevention Efforts with Non Penal Policy
}

\author{
$\underline{\text { Redyanto Sidi }}$ \\ Pembangunan Panca Budi University (UNPAB) Medan, Indonesia \\ Email : redyanto@dosen.pancabudi.ac.id
}

\section{Abstract:}

This study discuss about the efforts of corruption prevention with non penal policy. Criminal politics as a rational effort of the community in tackling crime, can be carried out operationally either through reasoning facilities or nonpenal facilities. Penal and nonpenal means are a pair that cannot be separated from each other, it can even be said that they complement each other in an effort to deal with corruption. Some social problems and conditions which can be conducive factors for the emergence of crime are clearly problems that cannot be overcome alone eyes with reason.

Keywords :

corruption prevention; effort; non penal policy

\section{Introduction}

The number of corruption cases until mid-2018 until now continues to increase. This increase is not only in the number of perpetrators of corruption who were convicted of law, but also in the amount of money that is corrupted.

Corruption practices such as abuse of authority, bribery, giving facilitation payments, illegal fees, giving rewards on the basis of collusion and nepotism and the use of state money for personal interests, are interpreted as acts of corruption and are considered common in this country. "The results of ICW monitoring in 2018 there were 1,053 cases with 1,162 defendants decided at all three levels of the court," ICW researcher Lalola Easter said at the ICW office, Jakarta, Sunday afternoon. "ICW data collection conducted from January 1, 2018-31 December 2018. ICW noted, the distribution of corruption decisions in 2018 was 926 defendants at the district court level, 208 at the high court level, and 28 defendants at the MA level

Corruption perpetrators who occupy the highest rank are private sector with a background of commissioners and company directors. They have 61 people. The other four highest ranking perpetrators were head of departments in government agencies (56 people), DPRD members (52 people), employees or staff in the district / city government (35 people), and agency heads (33 people)

Ironically, even though the efforts to eradicate it have been carried out for more than four decades, these corrupt practices continue, and there is even a tendency for the modus operandi to be more sophisticated and organized, making it even more difficult to overcome. Corruption must be eradicated, because of the negative impact it causes. Corruption burdens the Indonesian people, especially the poor, because actually corruption money can help reduce poverty if used properly.

Corruption also creates high macro-economic risks, endangers financial stability, compromises security and law and public order, and above all, corruption undermines the legitimacy and credibility of the state in the eyes of the people. Government spending from year to year is increasing so that Government duties are not carried out efficiently and economically, so the amount leaked or corrupted is increasing in number as well. The number $1 \mathrm{Law}$ of the Republic of Indonesia Number 17 of 2003 concerning State Finance states that State Finance is 
all state rights and obligations that can be assessed by money, as well as everything in the form of money or goods that can be used as state property due to the implementation of these rights and obligations. The existence of these rights and obligations has resulted in the State having to prepare a plan for the inclusion and expenditure of money as outlined in the State budget which consists of the State Revenue and Expenditure Budget (APBN) and separated state assets, for example in State enterprises.

Republic of Indonesia Law Number 31 Year 1999 concerning Eradication of Corruption Crime as updated with Republic of Indonesia Law Number 20 Year 2001 concerning Eradication of Corruption (hereinafter referred to as Corruption Eradication Law), states that the elements of corruption are as follows:

a. Performed by people or bodies.

b. There is an illegal act.

c. Favor yourself or other people or bodies.

d. Can be detrimental to the State's finance or the country's economy.

Sitting the issue of corruption related to State losses is:
a. Leakage
b. Waste
c. Deviation
d. Fraud.

The people can live in prosperity if efforts are made to tackle corruption as a whole, so that corruption can be the beginning of resolving various crises in Indonesia. In the context of the discussion of crime prevention issues, including corruption prevention, known as criminal politics.

Criminal politics as a rational effort of the community in tackling crime, can be carried out operationally either through reasoning facilities or nonpenal facilities. Penal and nonpenal means are a pair that cannot be separated from each other, it can even be said that they complement each other in an effort to deal with corruption. Some social problems and conditions which can be conducive factors for the emergence of crime are clearly problems that cannot be overcome alone eyes with reason. Based on this, the author will discuss it in this paper with the title, "Efforts to Overcome Corruption with Non Penal Policy".

\subsection{Corruption}

\section{Literature review}

Corruption comes from the Latin word "Corruptio" or "Corruptus", in French and English called "Corruption", in Dutch called "Corruptie". In Indonesian Encyclopedia called "Korupsi", from Latin Corruptio (Bribery), Corruptore (Damaging) where officials, state agencies misuse authority with the occurrence of bribery, forgery and other irregularities. Definition of corruption in Article 2 paragraph (1) The Corruption Eradication Law is not explicitly stated, as for the sound of the article, namely:

Anyone who violently violates an act enriches himself or another person or a corporation that can harm state finances or the economy of the country, is punished with imprisonment for life or imprisonment for a minimum of 4 (four) years and a maximum of 20 (twenty) year and a fine of at least Rp. 200,000,000 (two hundred million rupiah) and a maximum of 1,000,000,000 (one billion rupiah).

The nominal limit referred to as corruption can be seen in Article 11 letter c of the Republic of Indonesia Law Number 30 of 2002 concerning the Corruption Eradication Commission which states that "it involves a loss of at least Rp1,000,000,000.00 (one billion rupiah)" 
According to the Corruption Eradication Act which is included in the crime of corruption

a. Unlawfully committing acts enriching oneself or other people or a corporation that can harm the state or the country's economy (Article 2).

b. With the aim of benefiting themselves or other people or a corporation, misusing the authority, opportunity or means available to him because of a position or position that can harm the state's finance or the country's economy (Article 3).

c. Give gifts or promises to Civil Servants keeping in mind the power or authority inherent in the position or position.

According to Muhammad Ali, what is meant by corruption is as follows:

a. Corrupt (rotten, likes to accept bribes or bribes, uses power for his own sake and so on)

b. Corruption (rotten actions like embezzling money, receiving money and so on)

c. Corruptor (corrupt person).

Baharuddin Lopa quotes from David M. Chalwers outlining the meaning of the term corruption in various fields, namely concerning the problem of bribery which deals with manipulation in the economic field and concerns in the field of public interest.

Syed Husein Alatas states that corruption has the following characteristics:

a. Corruption always involves more than 1 (one) person. This is not the same as the case of theft or fraud.

b. Corruption is generally carried out in secret, unless corruption is rampant and so individuals in power in their environment are not tempted not to hide their actions, but even though the motives for corruption are kept confidential.

c. Corruption involves elements of obligation and mutual benefits. These obligations and profits are not always in the form of money.

d. Those who practice ways of corruption usually try to hide their actions, taking refuge behind legal justifications.

e. Those involved in corruption want decisions that are firm and able to influence those decisions.

f. Every act of corruption contains fraud, usually carried out by every public or public body (community).

g. Every form of corruption is betrayal of trust.

In line with the Corruption Eradication Law, in the criminal procedure law literature there are also several kinds of theories or systems of evidence in the form of a positive system of verification based on the law, a system of proof based on the belief of the judge and a system of proof of the middle system previous.

\subsection{Factors Causing Corruption Crime}

Corruption cannot be completely eliminated because humans basically carry corruption instincts besides hanif (not free from committing sin). Therefore, the most important thing is how to prevent the potential of corruption from becoming actual and how to narrow the scope of corruption systematically. Amien Rais, as quoted by Adnan Buyung Nasution, stated that "to find the right therapy needed a correct diagnosis."

According to Soejono Soekanto, the factors that influence law enforcement (including corruption) are:

a. Its own legal factor, which is limited to the Act only

b. Factors in law enforcement, namely those who form or implement the law

c. Factor facilities or facilities that support law enforcement 
d. Community factors are the environment in which the law applies or applies

e. Cultural factors are as a result of work, creativity, and taste that is based on human intention in life.

The same thing is also stated by Leden Marpaung that in order to create obstacles / barriers to criminal acts of corruption, a careful understanding of all the factors that cause corruption and all the things that support or influence it are needed. Opinions about the causes of corruption are also raised by Andi Hamzah, which according to him the causes of corruption are:

a. Lack of salaries of Civil Servants compared to needs that are increasingly increasing.

b. Indonesian cultural or cultural background which is the source or cause of widespread corruption.

c. Poor management and less effective and efficient controls that will provide opportunities for corruption.

d. Modernization breeds corruption.

Another opinion is also expressed by Evi Hartanti, who states the causes of corruption were:

a. The absence or weakness of leadership in key positions capable of providing inspiration and influencing behavior that tames corruption.

b. Weaknesses of religious and ethical teachings.

c. Colonialism, where a foreign government does not arouse the loyalty and compliance needed to stem corruption.

d. Lack of education.

e. Poverty.

f. The absence of strict punishment.

g. Scarcity of a fertile environment for anti-corruption behavior.

h. Government structure.

i. Radical change, where when a value system undergoes radical change, corruption emerges as a transitional disease.

j. The state of society where corruption in a bureaucracy can reflect the overall state of society.

Reflecting on some of the opinions of the experts above, it can be stated that the causes of corruption are:

a. Internal factors, namely the causes that arise from within the actor himself:

- Religious (weak faith)

- Moral damage

- Religious combination and moral damage

b. Extern factor, which is the cause that emerges from outside the actor / surrounding environment:

- Low income or salary

- Encouragement from the family (number of dependents such as children, wife and family)

- Opportunity factors

- Factors of weak supervision

- The attitude of the government that is tolerant of corruption

- Consumptive life style

- Economic growth is not in line with public moral growth

\subsection{Constraints in Eradicating Corruption Crimes}

a. Law Enforcement Failure 
The spearhead of law enforcement lies in the shoulders of law enforcement. The failure of the Public Prosecutor in providing evidence that can convince judges, moreover the disclosure of criminal acts of corruption is indeed difficult which handling requires concentration and precision, besides that it requires a truly understanding of the Law. eradicating corruption. Therefore, if the Public Prosecutor does not understand this, it will be difficult to eradicate corruption.

The difficulty of obtaining evidence and witnesses in uncovering corruption cases is one reason the High Prosecutor's Office is powerless to be able to drag the perpetrators of corruption in front of the court. Corruption practitioners and witnesses as well as those involved cover each other so that the parties The High Prosecutor's Office has difficulty obtaining the evidence and witnesses along with accurate and concrete data as a basis for prosecution.

\section{b. Reverse Proofing Efforts}

The Corruption Eradication Law has included the proof system, which is reverse proof (reversal of the burden of proof). This reverse proof is proof that is charged to the defendant, the defendant is considered to have committed a crime of corruption unless he can prove that he is not committing a criminal act of corruption.

With regard to the system of reversing the burden of proof, every civil servant or state administrator based on preliminary evidence has unbalanced wealth with income or source of income, then it is obligatory to prove the legitimacy of the assets obtained in article 37a, 38a, 38b.

Against this burden of reversed evidence, of course, there are indications that benefit the perpetrators of corruption include:

- People suspected of corruption have the opportunity to release themselves from corruption charges if the application of the burden of proof is not monitored

- There will be a compromise in the verification, the perpetrator may manipulate the wealth results in all ways including the power / position

- Reverse proof means providing opportunities to expand corruption that can cause degradation in a country

- If there are perpetrators who succeed in proving their innocence in all ways, then this will be a jurisprudence for other actors to escape the law.

Any crime prevention efforts, including corruption, of course there will be obstacles / obstacles in eradicating in all sectors, as for those obstacles, namely:

- Actors of corruption have certain qualities both in terms of ability and social standing.

- Actors of corruption generally have qualities as smart people, people who have authority and opportunities.

- The modus operandi is complicated and is done by sophisticated techniques.

- Because corruption is carried out by people who are smart / educated and have authority, then the act of corruption can be covered in a long period of time, so it is difficult to know especially to find the necessary evidence and efforts to restore state losses.

- Witnesses and witnesses are often less cooperative actors of corruption are deliberately complicating investigations.

Another opinion which states weakness is that there are several causes of weak law enforcement in Indonesia, including:

Firstly, weak law enforcement in Indonesia is an aspect of party domination in a number of state institutions, not only in legislative institutions, party domination also spreads to financial institutions, ministries, and a series of executive institutions as policy implementers, so pragmatic reasoning and interests sink the professionalism of national leadership. Citing the Kompas daily 
on October 17, 2011, Lecturer in Political Sciences, Gadjah Mada University, Yogyakarta, AA GN Ari Dwipayana; lecturer in State Science at Airlangga University, Surabaya, Radian Salman; and senior researcher at the CenterFor Strategic and International Studies, J Kristiadi, acknowledging the dominance of political parties in government in this country. Political parties become a source of national leadership, but too dominant political parties endanger democracy.

Democratization with the aim of welfare of the people originally made the value system in managing this nation. Here demanded integrity, professionalism of leaders in accommodating public interests. The dominance of the party in the management of the nation, directs Indonesia to the "State of Partitocracy", of course this does not become a panacea in the chronic disease of corruption in this nation. Even the area of political intervention is more violent in efforts to uphold law in justice in Indonesia.

Secondly, Professor of Criminal Law at the University of Indonesia, Jakarta, Indriyanto Seno Adji, quoted in the Kompas Daily on October 17, 2011, revealed that the intervention of the authorities, political power, and economic power began to become common in Indonesia. Rulers who should provide encouragement actually hamper efforts to eradicate corruption. Even the owners of political power who conspire with economic forces, such as entrepreneurs, become obstacles in eradicating corruption.

Thirdly, this condition is exacerbated by the lack of synergy between the police, prosecutors and the Corruption Eradication Commission. The lack of consolidation of law enforcement agencies is what is used as a gap for certain parties to intervene in handling cases. This condition was used as an entry point to weaken law enforcement agencies.

\section{Discussion}

Criminal policies in general can be grouped into two parts, namely:

a. Criminal policy by using criminal law (penal policy) through criminal law application.

b. Criminal policy by using facilities outside criminal law (non-reasoning policy) through influencing views of society on crime and punishment (mass media) and prevention without punishment.

Crime prevention efforts (including corruption) can be broadly divided into two, namely through the "reasoning" line (criminal law) and through "nonpenal" channels (not / outside criminal law). Both of these facilities (reason and nonpenal) are a pair that can not be separated from each other, it can even be said that they complement each other in efforts to deal with crime in the community.

\subsection{Penal Policy Efforts}

The prevention of corruption by using the means of punishment through the criminal justice system is formulated as follows:

a. Resolving crime cases that occur when people are satisfied that justice has been upheld and the wrongdoers have been convicted.

b. Make sure that those who have committed acts of crime repeat their crimes.

The use of penal facilities through the criminal justice system in handling criminal acts of corruption must still be carried out by law enforcement officials both the Police, Prosecutors, Judges and KPK. This is confirmed by the opinion of Herbert L. Packer in his book "The Limits of the Criminal Sanction", which says that: 
a. Criminal sanctions are very necessary; we cannot live, now or in the future, without criminality.

b. Criminal sanctions are the best tools or means available, which we have to deal with major and immediate crimes or dangers and to deal with threats from danger.

c. Criminal sanctions are one of the main guarantor, and one day is the main threat of human freedom. He is a guarantor if used sparingly, meticulously and humanely, he is a threater if used carelessly and forcibly.

Weaknesses / limitations of the ability of criminal law in dealing with criminal acts of corruption, namely:

a. Its effectiveness depends entirely on the infrastructure capabilities supporting the facilities and infrastructure, the professional capabilities of its law enforcement officers, and the legal culture of the community. The weakness of this infrastructure will reduce input in the criminal justice system, or in other words the criminal offenders who can be detected will decrease, so that the hidden criminal increases. The ability to carry out investigations and verification both in the preliminary examination and in the court session is a variable that greatly influences the effectiveness of the criminal justice system.

b. The causes of corruption are so complex, they cannot be overcome by criminal law which is beyond the scope of criminal law

c. Criminal law is a small part (subsystem) of the means of social control that is not possible to overcome the problem of corruption that is very complex (related to moral / attitudinal problems, problems of lifestyle needs and culture and social environment, problems of economic needs / demands and socio-economic welfare, economic structure / system problems, system / political culture problems, development mechanism problems and weak bureaucracy / administrative procedures (including supervision systems) in the fields of finance and public services.

d. The use of criminal law in tackling crime is only a "curricular symptom", therefore criminal law is only "symptomatic treatment" and not "causative treatment"

e. Criminal law sanctions are "remedium" which contain contradictory / paradoxical characteristics and contain negative elements and side effects

f. The criminal system is fragmentary and individual / personal, not structural / functional in nature: The functioning of criminal law requires a more varied and more demanding supporting means of "high costs".

Indonesian Legal Division Coordinator of Corruption Watch Febri Diansyah warned that if the government really wanted to eradicate corruption, the prosecutor's office and the police should be strengthened. As a law enforcement agency, the state should be able to get positive energy from the public, so that corruption can be lost in this country. Therefore, law enforcers must dare to be fair in handling legal cases. The people must be convinced of the seriousness of law enforcement, do not cut down the vote, and do not choose time to cut down because it will backfire itself for the survival of our nation.

In view of the limitations / weaknesses of the ability of criminal law to deal with the corruption cases mentioned above, efforts to tackle corruption cannot only use the means of justice but also use non-public facilities. However, when viewed from a criminal political perspective on a macro basis, the policy of crime prevention by using facilities outside criminal law or non-reasoning policy is the most strategic policy. This is because non-reason policies are more of a preventive measure against crime. Penal policy is to deal with and eliminate conducive factors that cause crime. 
Efforts to tackle corruption are complex problems and are a common obligation, in this regard Barda Nawawi Arief states that:

Corruption problems are related to various complexities of problems, including moral issues / mental attitudes, problems of lifestyle and culture and social environment, problems of economic needs / demands and socio-economic disparities, structural / economic problems, system / political culture problems, mechanism problems development and weak bureaucracy / administrative procedures (including supervision systems) in the fields of finance and public services. So, the causes and conditions that are criminogenic for the emergence of corruption are very broad (multidimensional), which can be in the fields of moral, social, economic, political, cultural, bureaucratic / administrative and so on.

Furthermore, Barda Nawawi Arief said that criminal law has limitations / weaknesses as a means to overcome crime (including eradicating corruption), namely:

a. The causes of crime (especially corruption) are very complex and are beyond the scope of criminal law.

b. Criminal law is only a small part (subsystem) of a means of social control that is impossible to solve the problem of crime as a very complex humanitarian and social problem (as a socio-psychological, socio-political, socio-economic, socio-cultural, etc.) problem.

c. The use of criminal law in dealing with crime is only a "kurieren am symptom" (prevention / treatment of symptoms), therefore, criminal law is only "symptomatic treatment" and not "causative treatment".

d. Sanctions for criminal law are only "remediums" which contain contradictory / paradoxical characteristics and contain negative elements and side effects.

e. The criminal system is fragmentary and individual / personal, not structural / functional.

f. Limited types of criminal sanctions and systems for formulating criminal sanctions that are rigid and imperative.

g. The functioning / functioning of criminal law requires supporting facilities that are more varied and more demanding "high costs".

Sudarto expressed an integral policy in tackling corruption as follows:

A Clean Government, where there is no or at least not many acts of corruption, cannot be realized only by legal regulations, even though it is a criminal law with sharp sanctions. The scope of criminal law is limited. Efforts to eradicate indirectly can be done with actions in the field of politics, economy, and so on.

\section{Romli Atmasasmita stated that:}

The success of eradicating corruption is not only solely located or dependent on policies in the field of law and its implementation but also must be accompanied by policies in the fields of politics, management, economy, social, culture, and strengthened by increasing religious awareness, codes of ethics, bureaucracy, transparency and integrity.

Efforts to tackle corruption with a non-reason policy can be done in several ways, including:

a. Pre-entif

Preemptive efforts can be made by families or elementary schools (SD), junior and senior high schools by socializing early on to the generation of people about the effects and dangers of corruption and instilling honesty values based on religious values and a sense of responsibility.

b. Preventive 
Preventive measures can be carried out by all levels of society where crimes that have been involved tend to be involved as a means of preventing corruption, namely:

- Abolitionistic efforts, namely efforts to overcome crime by first studying the causes of negative things, then taking action in the form of eliminating or at least reducing the causes of persons who consciously and with certain intentions of corruption, and increase awareness or close the possibility for corruption. This effort can include experts such as psychologists, criminologists who are needed to conduct scientific field research to obtain data on the causes of corruption.

- Efforts to moralize, namely the efforts to overcome the intended ones are to restore and nurture the mental, moral and faith of law enforcers, politicians, officials, and the wider community so that they can avoid corruption.

c. Reformative

Reformative efforts can be carried out by the government by increasing the morale of human resources can be started in the initial process (acceptance) and efforts to apply sanctions that are morally more severe against perpetrators of corruption means if proven guilty not only fired with disrespect but also blacklisted perpetrators and family tree. Other reformative efforts are by implementing a system of transparency of work in government agencies and increasing the economic welfare of all levels of society.

Soedarto once said that "Karang Taruna activities, scout activities and the cultivation of community mental health with religious education are nonpenal efforts in preventing and overcoming crime". In consideration of Resolution No. 3 of the 1980 UN 6th Congress on "Effective Measures To Prevent Crime", among others, stated:

- That prevention of crime depends on the human person himself (that crime prevention is dependent on man himself)

- That the crime prevention strategy must be based on efforts to arouse / raise the spirit or soul of the human being and try to strengthen the belief in its ability to do good (that crime prevention strategies should be based on the spirit of man and reinforcement).

All forms of nonpenal effort should be based on what is known as Ibda 'Binafsika (start from yourself), which means starting to prevent corruption from yourself, this can be done in every activity we have because actually humans have the ability to do that.

\section{Conclusion}

4.1 Factors causing corruption can be stated, among others:

a. Internal factors, namely the causes that arise from within the actor himself:

- Religious (weak faith)

- Moral damage

- Religious combination and moral damage

b. Extern factor, which is the cause that emerges from outside the actor / surrounding environment:

- Low income or salary

- Encouragement from the family (number of dependents such as children, wife and family)

- Opportunity factors

- Factors of weak supervision

- The attitude of the government that is tolerant of corruption 
- Consumptive life style

- Economic growth is not in line with public moral growth

4.2. Constraints faced in efforts to overcome corruption are:

a. Failure of law enforcement

b. There is reverse proof

c. Perpetrators have certain qualities both intellectual abilities and education and experience so that they can do any means to prove their innocence.

d. Social position and authority of actors in their work so that acts of corruption can be covered in a long period of time, so that it is difficult to know especially to find the necessary evidence and efforts to return money to state losses.

e. The modus operandi is complicated and is done by sophisticated techniques

f. Witnesses and witnesses are often less cooperative

g. Corruption perpetrators deliberately complicate investigations.

4.3. Efforts to overcome corruption with a non-reason policy can be done by:
a. Pre-entif
b. Preventive
c. Reformative
d. Ib'a Binafsika

A. Books

\section{References}

Adnan Buyung Nasution, Korupsi, Kolusi, dan Nepotisme di Indonesia, Yogyakarta: Aditya Media, 1999. Andi Hamzah, Perkembangan Hukum Pidana Khusus, Jakarta: Rineka Cipta, 1991. ,Korupsi di Indonesia Masalah dan Pemecahannya, Jakarta: Gramedia, 1991.

Arya Maheka, Mengenali dan Memberantas Korupsi, Jakarta: Komisi Pemberantasan Korupsi, 2006.

Baharuddin Lopa,Kejahatan Korupsi dan Penegakean Hukum, Jakarta: Rineka Cipta, 1992.

Barda Nawawi Arief, Beberapa Masalah Penegakan Hukum Pidana dalam Pemberantasan Korupsi, Bandung: PT. Citra Aditya Bakti, 2000.

------, Kapita Selekta Hukum Pidana, Bandung: PT. Citra Aditya Bakti, Bandung, 2003.

------, Bunga Rampai Kebijakan Hukum Pidana (Perkembangan Penyusunan Konsep KUHP Baru), Jakarta: Kencana, 2010.

Bohari, Pengawasanan Kenangan Negara, Jakarta: Rajawali,1992.

BPKP, Upaya Pencegahan dan Penanggulangan Korupsi pada Pengelolaan Pelayanan Masyarakat, Jakarta:Tim Pengkajian SPKN RI, 200

Darwan Prinst,Pemberantasan Tindak Pidana Korupsi, Bandung: PT.Citra Aditya Bakti, 2002.

Evi Hartanti, Tindak Pidana Korupsi, Jakarta: Sinar Grafika, 2005.

Leden Marpaung, Tindak Pidana Korupsi: Pemberantasan dan Pencegaban, Jakarta: Djambatan, 2004.

M. Hamdan,Politik Hukum Pidana, Jakarta: PT. Raja Grafindo Persada, Jakarta, 1997.

M. Subagio, Hukum Kenangan Negara. Jakarta:Rajawali, 1991.

Muhammad Ali, Kamus Lengkeap Bahasa Indonesia, Jakarta: Amani, 1999.

Muladi, Kapita Selekta Sistem Peradilan Pidana, Semarang: Badan Penerbit Universitas Diponegoro, 1995.

Romli Atmasasmita, Reformasi Hukum dan Hak Asasi Manusia dan Penegakan Hukum, Bandung: CV Mandar Maju, 2001.

Sudarto, Hukum dan Hukum Pidana, Bandung: Alumni, 1981.

------, Kapita Selekta Hukum Pidana, 1981.

Soerjono Soekanto, Faktor-Faktor Yang Mempengarubi Penegakan Hukum, Jakarta: Rajawali Pers, 2010. 
Syed Husein Alatas, Sosiologi Korupsi, Jakarta: Rineka Cipta, 1986.

B. Legislation

Undang-Undang RI Nomor 31 Tahun 1999 tentang Pemberantasan Tindak Pidana Korupsi

Undang-Undang RI Nomor 20 Tahun 2001 tentang Perubahan Undang-Undang RI Nomor31 Tahun 1999, Tentang Pemberantasan Korupsi

C. Internet

"ICW: Kerugian Negara akibat Korupsi pada 2018 Capai Rp 9,29 Triliun" melalui https://nasional.kompas.com/read/2019/04/28/15294381/icw-kerugian-negara-akibatkorupsi-pada-2018-capai-rp-929-triliun, accessed on November 162011.

Pandangan Islam Tentang Kehidupan, http://www.oocities.org/tarjikh/PEDOMAN HIDUP ISLAMI/bag kedua.htm, accessed June 162019.

Indra Jaya, Korupsi dan Lemahnya Penegakan Hukum Di Indonesia, http://politik.kompasiana.com, accessed June 162019.

Wawan Budayawan, dapat dilihat pada http://myzone.okezone.com, accessed June 162019.

Jumlah Kasus Korupsi Meningkat 50\%, dapat dilihat padahttp://vivanews.com, accessed June 16 2019.

Magazines, Articles and Others

Kompas, Fokus, “Memerangi Korupsi, Hanya Satu Kata: Lawan”, No. 5 p. 2 June 25, 2011.

Dokumen Sixt UN Congress, Report, 1981

Dokumen A/CONF. 121/L.15, Seventh UN Congress, 1981. 